\title{
Beyond Structural-Functional Perspective: A Critical Heart Searching For Dalit, Tribal and Gender in Indian Sociology
}

\author{
Dr.Rabindra Garada \\ Faculty, Post Graduate Department of Sociology, Utkal University, Vani Vihar, Bhubaneswar, Odisha
}

\begin{abstract}
Functionalism is the most outstanding Intellectual acumen of European world, but among the absolute elitist approaches ever explored by early pathfinders of sociology in comprehending the social reality worldwide. No doubt, it has been excelled as an exceptional academic perspective among all social science perspectives worldwide; however, its face value is getting redundant in the country like India, where the dominant social structures push the subalterns down and pulls them out of their established social patterns. It runs away from the realities and gets enticed with Indian dominant ideology and western methodology. The tragedy is that it does not endorse the salient reflections of cultural diversities and pluralism nurtured by the subaltern castes, tribes and gender in the Indian society. Our study reveals that going beyond the prospect of the structural-functional perspective on Indian society will definitely be an uphill task. And instead of, going right through the accounts of the early travelers' visits, orientalist' studies, missionary views, British officials' ethnographic studies, indological perspective, Marxist perspective, etc on Indian society has been a critical heart searching for the subaltern people and their ethnic autonomy in Indian sociology. Addition to that, the Indological hegemony, and its related functional ideology still persist like "cultural watchdog" against any possibility of the subaltern perspective in contemporary India. Unfortunately, the authentic essence and liberating presence of the subaltern groups in Indian sociology is largely missing. Contrary to it, although, the subaltern consciousness as a liberating intellectual project has been gaining momentum but grappling with stiff oppositions. Since the dominant discourse on mainstream sociology has grudge against such development, it requires more scrutiny and debate for the sociology in India. Thus, an analytical reviews but critical history of Indian sociology has been sufficed to our purpose under the study. We have developed a resourceful analytical framework with Figure format in a comparative knowledge base for the study of Indian society in detail.
\end{abstract}

Keywords: Structural-functionalism, theoretical perspective, Indian Sociology, Indology, Marxist perspective, Subaltern perspective, Dalit.

\section{Introduction}

The discourse on "macro-sociology" versus "micro-sociology" and "value relevant sociology" versus "value free sociology" and "value neutral sociology" has been highly controversial since the balkanization of the sociological perspectives began at the global level. Unfortunately, the possibility of middle range sociological perspective was not comprehended comfortably for the substantive expansion of early sociology, and rather, the prospect of "macro-sociology", "value free sociology" and "value neutral sociology" has been prioritized over that of "micro sociology" and of "value relevant sociology" at the global level. The macro versus micro controversy therefore, goes beyond mere conceptualization of the "abstract grand theorizing" (AGT) versus "empirical ground theorizing" (EGT) on social reality as generally perceived in the global sociology. In the macro-level, the relevance of sociology is the question of sociological universalism, sociological enlightenment, value-free assumption, cultural relativism, human relationship, human dignity, etc, and above all an objective comprehension of the global people, global societies and their institutions in general. However, in the microlevel, it is the sociological regionalism, ethnocentric world views, sociological distinctiveness, ethnic diversities, human rights, etc, and above all an objective comprehension of the local people, local societies and their local institutions in particular. The relevance of sociology in macro and micro levels therefore, has been polarized into two modes of thinking and theorizing. In fact, the classical sociological theories having based on derivatives of the macro sociological knowledge house (MSKH) could not run through the micro-sociological possibilities in the early phase of emergence of the sociology as a social science discipline worldwide. The "macroization" as if, the process- "Universalization" of the global great traditions has been prioritized over the "microization" as if, the process- "Parochialisation" of the global little traditions. Therefore, the divergence thesis of the macro-micro theorizing has been suppressed more than that of their feasible convergence since the inception of the subject "sociology" in the western world. The universal facts for which the western sociological concepts, theories, thoughts, paradigms, methods, etc got over dominated and over imposed on that of the Indian sociology, have been saliently reflected through the overviews of major theoretical literatures in India over the decades (see, Patel, 2010; Nagla, 2008; Singh, 2004; Srinivas,1997; Cohn, 1997; Ritzer,1996; Singhi,1996; 
Singh,1996; Dhanagre,1993; Oommen and Mukherjee, 1986; Singh, 1986; Mukherjee,1979; Ambedkar,1979; Mukherjee,1977; Dube,1973; Singer, 1972; Gouldner,1970; Unnithan et al,1967; Dube, 1958\&1952; Srinivas, 1952 and others). The issues of the people's primordial ethnicity centered on their sex, races, castes, languages, religions, regions, etc, in addition to their cases of marginalization and subordinations have consequently been predicted as the cases of sociological regionalism leading to the elitist approach in the sociological world. This has been assumed to be reflected in the classical sociological perspectives propounded by the great founding fathers of sociology like August Comte, Emile Durkheim, Karl Marx and Max Weber in the western world. Unfortunately, these great founding fathers were undoubtedly, though by products of their particular regions and regional ethnicities, but imposed their cultural constructs over rest of the sociological world without even having a qualm of self introspection. Further, it is an objective introspection that the psychic levels of all classical theorists were seemed to be positivistic and rationalistic in the beginning. In fact, what could be studied objectively charged with the battery of "Etic methodology" and "collective rationality" became the subject matters of sociology. On the contrary, which cannot be studied objectively, is either repeatedly assumed as irrational subject or an obvious antithesis to the positivistic order of the society. Addition to that, the whole store house of indigenous knowledge which is stemming from the very people who experience and internalize the ground social realities stays as the blind beliefs and superstitions, because it could not be scanned through the positivistic machines of the early classical sociology.

In course of time, an affectionate shift was occurred in sociology in term of its ideology, approach and application in the western world. Consequently, the ontological dualism like objective versus subjective approaches, etic versus emic perspectives, etc were, though highly discussed, but resulted in favour of the former at later time. In course of time, the participatory observation and field study traditions got comfortably dragged into sociology which was called as social anthropology later on. In fact, the structural functionalism of social anthropology was not delinked from the functional thread of Comte, Spencer and Durkheim that once developed in reaction to the chaos and upheavals of French and Industrial revolutions in the western world. This linkage could successfully get established in sociology, another lease of life that heavily got incorporated into sociological syllabus of universities at global level. The "consensus universal" of Comte which explains the society as functionally organized system of which the consisted components are in a relational harmony. It was better explained through "organisimic analogy" of Spencer, Pareto's "system of equilibrium" and Durkheim's "causal functional analysis" (see, Nisbet and Bottomore 2004; Ritzer \&Smart, 2001 and Turner, 1999). Further, Bronislaw Malinowski's "individual functionalism" and Radcliffe Brown's "structural functionalism" brought in many accepted versions of functionalism with fieldwork traditions. But each facet of the functionalism from Comte to Brown was aimed to restore the primacy of system over its parts. R. Brown as an anthropologist had his field study at Andaman Islander in India in early $20^{\text {th }}$ century (Madan and Majumdar, 1956). After some time in 1919 to 1922 sociology was opened as a subject in Bombay University.

Functionalism is one of the most beautiful creations of western sociology but remains one of the elitist approaches to understand the society at the global level. It has been excelled as an outstanding academic discipline among social sciences worldwide. But, its face value is getting redundant in these days in India. It runs away from the realities and get seduced with Indian dominant ideology and western methodology. It has never seen the day light staying in the moonlight areas of the intellectual elite. The people who live in the sunlight areas of urban India, and the people who live amidst the den of casteism, patriarchy and marginalization in rural India are highly romanticized. As for instance, C.Metcalfe, H.Maine and Baden-Powell studied the Indian villages as isolated sites (Srinivas and Shah, 1960). Charles Metcalfe's Indian village as self contained little republic, and many others' studies on rural societies greatly suffered from the crisis of the subaltern autonomy and their original ethnicity. The tragedy is that it does not endorse the salient reflections of cultural diversities and pluralism held by the subaltern castes, tribes, most importantly female gender, etc as autonomous categories/identities in Indian society. Unfortunately, Gandhi's idea of the Indian village as the site of Indian civilization is much emphasized than Nehru's idea on village as the site of backwardness and Ambedkar's idea on village as the site of oppression (Jodhka, 2002 a \& b). In fact, when the western functionalism as an important intellectual landmark started in the context of French and Industrial revolution, the Indian sociological functionalism started responding to the western sociology but not reacting to the crisis of colonialism and of the nation-states at that time. Many sociologists argue that the Indian sociology followed the middle part - between sociological universalism and sociological regionalism just before independence and just after independence (see Singhi, 1996; Dhanagre, 1993 and Oommen and Mukherjee, 1986).

The G.S.Ghurye, the father of Indian sociology got influenced by the structural functional approaches of anthropological traditions, and later M.N. Srinivas and other adhered to it which had lifted the Indian sociology to a height of a global standard. In fact, the founding pioneers/followers of Indian sociology were highly got charged with the batteries of Western positivism. Addition to that some of the early sociologists' interdisciplinary backgrounds got resulted in the supplementary or complementary character of Indian sociology, as for instance, sociology was started with civics in Bombay University during Patrick Geddes and 
G.S.Ghurye time, with economics in Lucknow University during R.K Mukherjee and D.P.Mukherjee time and was with historical and philosophical traditions by B.Sarkar and others in Calcutta University (Singh, 2004; Singhi 1996 and Mukherjee, 1979). In other words, before sociology getting into its unique Indian social worlds got highly biased with the dominant ideologies of western structural-functionalism. Later, the functionalism became sociology, and the sociology became functionalism in India. In this respect, fortunately or unfortunately, the rural class, caste, gender and rural societies were studied with functional methods and ideologies. Thus, since beginning the Indian sociology has gone astray neglecting the diversified and specific societies of castes, peasants, tribes and gender in general. In fact, for over more than nine decades of origin of the Indian sociology in Bombay University in 1919, it has been a critical heart searching for the "Dalit Bahujan" (marginalized and oppressed people) and their authentic identities in the Indian sociology.

\section{I.1.Objectives}

In this back drop, we have modestly tried to understand the value relevance of theoretical perspectives of Indian sociology for the subordinated, marginalized and voiceless sections in India. We have critically comprehended the perpetuation of the structural functionalism as the sociological knowledge base for Indian sociology. After a brief critically overviews on the frameworks of functionalism, neo-functionalism, structuralism and post-structuralism, we have analyzed the locations and identities of the subaltern dalit, tribal and women in Indian sociology through different early foreigners' accounts and later theoretical perspectives. We have constructed a resourceful analytical framework with Figure format in a comparative knowledge base for the study of Indian society in detail.

\section{I.2. Analysis of the Study}

This paper consists of the four main parts. The Part-I consists of introduction, objectives and analysis of the study. The Part-II consists of an analytical reviews and discussion on structural-functionalism along with some figure such as Figure 1: value relevance of structural-functionalism, Figure-2: value relevance of neofunctionalism and Figure 3: value relevance of structuralism and post-structuralism. The Part-III consists of an analytical finding with its sub-parts such as critical heart searching for the subaltern people through the theoretical perspectives, searching through early travelers' accounts, searching through European accounts, searching through orientalists' accounts, searching through missionary accounts, searching through the British officials' accounts, searching through Indological perspectives, searching through structural functional perspectives, searching through Marxist perspectives and searching through subaltern perspectives. These accounts and perspectives have been briefly analyzed and discussed through two figure format such as Figure 4: sociological knowledge developed and used in the colonial history, and figure 5: sociological knowledge developed and used in Indian sociology. The Part-IV consists of the conclusion where the article has been briefly summed up.

\section{Analytical Reviews and Discussion}

The knowledge base of structural functionalism has been developed through the extensive use of the word "social structure" the definition of which is highly controversial, and still undergoing academic research. Broadly speaking, the idea of functionalism, structural functionalism and neo-functionalism has been emerged and got established worldwide on some basic premises of social structure such as social structure as if linguistic structure, social structure as if social system, social structure as if pattern of relationship/action, social structure as if a sequence of order, social structure as if differentiation and social structure as if mathematical structure (Moore, 1967).

\section{II.1. Knowledge Base of Structural Functionalism and its Application}

In fact, the structural functional perspectives propounded by T. Parsons, R.K. Merton, Levi-Strauss, S.F. Nadel and host of others functionalists remain impractical projects, and rather, have been imposed on the academic contents of the subject "sociology" worldwide (see Gouldner,1970 and Doshi,2003). The project "functionalism" is being highly anti-individualism and anti-pluralism, revealing itself likes an oppressive watchdog against all the possibilities of intellectual autonomy of gender, dalit and indigenous people in India. It is because of the fact that structural-functionalism cannot be value free. As for, instance, the teleological (purpose behind the social structure) and tautological (parts as determined in the order of whole) frameworks of structural-functionalism have been revealed through the ideology and academic applications of the classical sociological and anthropological works throughout the world. We can observe from the Table 1 that while the British structural-functionalists view social structure as concrete reality, the French structural-functionalists and the American structural-functionalists view it as a model behind the reality and a conceptual scheme of social system respectively (see, Merton, 1975 and Nadel, 1957). 
Figure 1: Value Relevance of Structural-Functionalism

\begin{tabular}{|l|l|l|l|}
\hline Structural- Functionalists & $\begin{array}{l}\text { Ideology to Understand } \\
\text { Social Reality }\end{array}$ & $\begin{array}{l}\text { Approaches to Study Social } \\
\text { Reality }\end{array}$ & $\begin{array}{l}\text { Application of Ideology/ } \\
\text { Study in Real Life }\end{array}$ \\
\hline $\begin{array}{l}\text { British Structural Functionalist } \\
\text { (A.R.Radcliffe Brown) }\end{array}$ & $\begin{array}{l}\text { Social Structure as Social } \\
\text { Reality }\end{array}$ & $\begin{array}{l}\text { Positivism/ Macro Approach } \\
\text { (Organic Analogy) }\end{array}$ & Conservatism/No Change \\
\hline $\begin{array}{l}\text { French Structural-Functionalist } \\
\text { (Claude Levi-Strauss) }\end{array}$ & $\begin{array}{l}\text { Social Structure as Model } \\
\text { behind Social Reality }\end{array}$ & Linguistic Analogy & Conservatism/No Change \\
\hline $\begin{array}{l}\text { America Structural-Functionalist } \\
\text { (Talcott Parsons) }\end{array}$ & $\begin{array}{l}\text { Social Structure as Social } \\
\text { System }\end{array}$ & $\begin{array}{l}\text { Positivism Macro Approach Conservatism/No Change } \\
\text { (System Analogy) }\end{array}$ & C \\
\hline
\end{tabular}

Source: Our Own

While the British structural-functionalists extensively use the organic analogy and the American structural-functionalists use the analytical system analogy, the French structural-functionalists apply the linguistic analogy in studying the social phenomena (ibid). All of them are conservative, no-changers and status quoists, but belief in the use of positivism for the study of the society. In fact, they have applied positivistic approach but have miserably failed to become true empiricists and value neutral, because they cannot rescue themselves of their conservatism, super imposition of whole over parts, etc. Reacting to the over proliferation of the structures- "teleology" and "tautology" in the functional paradigm, the neo-functionalists were quite ambitious in their "reformative revivalism" of the project "functionalism", as it is observed from the Figure-2. The neo-functionalism has been a liberal attempt to rectify the conservatism inflicted in the functionalism.

Figure-2: Value Relevance of Neo-Functionalism

\begin{tabular}{|c|c|c|c|}
\hline Neo-Functionalists & $\begin{array}{l}\text { Ideology to Understand } \\
\text { Social Reality }\end{array}$ & $\begin{array}{l}\text { Approaches to Study Social } \\
\text { Reality }\end{array}$ & Application of Ideology/ Study in Real Life \\
\hline $\begin{array}{l}\text { Niklas Luhmann, } \\
\text { Jaffrey Alexander, } \\
\text { Paul Colomy \& } \\
\text { Richard Munch }\end{array}$ & $\begin{array}{l}\text { Reconstruction and } \\
\text { Revision of Functionalism }\end{array}$ & $\begin{array}{l}\text { Positivism/Post-Positivism } \\
\text { (Theory and Empiricism). } \\
\text { Macro-Micro Approach }\end{array}$ & 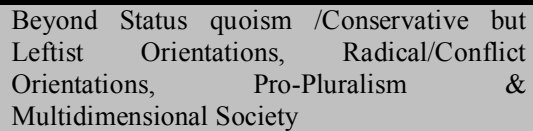 \\
\hline
\end{tabular}

Source: Our Own

Anthony Giddens, Niklas Luhmann, Jaffrey Alexander, Paul Colomy, Mark Gould, Neil Smelser and Richard Munch were highly critical of functionalism in 1980s(Turner,1999 and Doshi, 2003). However, they could not overthrow the works of the grand foundational functionalism professed by T.Parsons. Rather, the Parsonsian functionalism was reconstructed and revived with some modifications by Niklas Luhmann and Jaffrey Alexander- the so called champions of the neo-functionalism at international level. In this regard, S.L.Doshi rightly observed that the neo-functionalism is an old wine in new bottle (Doshi, 2003). Of course, the neo-functionalism is yet to be grounded comfortably in Indian sociological world. And also, the neofunctionalists' tendency of revivalism and reconstructions cannot help the subaltern dalit, tribes and gender, because it has not been rooted out of the rhetoric and rubrics of the project "functionalism". Unfortunately, the linguistic structuralism and post-structuralism, and their intellectual frames of reference have been highly elitized further complicating the threads of functionalism. Now, the "deconstruction" project of Derrida and the "discourse analysis" of Foucault generate though much heat among the top intellectuals in the higher level, but yet to generate any light for the Indian researchers who wish to see and observe the empirical social situations in rural India. It has been analyzed in the Figure 3 that the both strcturalists and post-structuralists are antiempiricism and anti-historicism in their approaches to study the social reality. But the former beliefs in the existence of social reality while the latter doubts that existence.

Figure 3: Value Relevance of Structuralism and Post-Structuralism

\begin{tabular}{|c|c|c|c|}
\hline Structuralists & $\begin{array}{l}\text { Ideology to Understand } \\
\text { Social Reality }\end{array}$ & Approaches to Study Social Reality & $\begin{array}{l}\text { Application of Ideology/ Study in } \\
\text { Real Life }\end{array}$ \\
\hline $\begin{array}{l}\text { Ferdinand } \\
\text { Saussure }\end{array}$ & $\begin{array}{l}\text { How language functions as } \\
\text { a systems of meaning or of } \\
\text { producing meaning }\end{array}$ & $\begin{array}{l}\text { Linguistic approach and } \\
\text { analogy/syntagmatic/paradigmatic/semio } \\
\text { tic/ synchronic (non-historical) analysis/ } \\
\text { anti-empiricist and anti-historicism }\end{array}$ & $\begin{array}{l}\text { Symbolic understanding as meaning } \\
\text { is there between the words and word } \\
\text { has no relation with real objects }\end{array}$ \\
\hline Post- Structuralists & $\begin{array}{l}\text { Ideology to Understand } \\
\text { Social Reality }\end{array}$ & Approaches to Study of Social Reality & Application in Real life \\
\hline Jacques Derrida & $\begin{array}{l}\text { Language lacks fixed/ } \\
\text { inherent meaning, and } \\
\text { rather, remains contingent } \\
\text { and unstable }\end{array}$ & $\begin{array}{l}\text { Anti-empiricism/Anti- } \\
\text { historicism/Deconstruction/ } \\
\text { criticism }\end{array}$ & $\begin{array}{l}\text { Help finding the hidden meaning of } \\
\text { social structure, and its meaning of } \\
\text { meanings, multiple meanings and } \\
\text { unstable meaning }\end{array}$ \\
\hline Michel Foucault & Discourse & Anti-Empiricism/Anti-Historicism & $\begin{array}{l}\text { Nothing is found stable on single } \\
\text { objective ground }\end{array}$ \\
\hline
\end{tabular}

Source: Our Own 


\section{Analytical Finding}

It seems that directly or indirectly the Indian sociologists have been studying the Indian people and their societies in term of some of these knowledge bases of "structural-functionalism" (see Table1, 2 \& 3). The entire kinship and family studies are highly based on the model of linguistic structuralism, the entire caste systems are highly based on the model of structural patterns of relationship/action, and the entire village studies are highly based on the model of structural system and its structural sequence of order.

\section{III.1.Critical Heart Searching for the Subaltern Caste, Tribe and Gender through Theoretical Perspectives}

Unfortunately, the structural functionalists have not gone beyond understanding and simplifying the western traditions or at best, applying these traditions in a sophisticated statements, languages and jargons or by lifting them as intellectual capitalists. As a result, it seems that the Indian sociologists, as if have withdrawn themselves from the real life of people, and were attracted toward the elitist and dominant perspectives on India social realities. The statue quoists' argument cannot hold back the truth of caste, peasant and gender in India. It seems starting from Bombay University to J.N.U., the Indian sociologists are struggling hard for functionalism like all Sanskrit pundits who had struggled for thought in the mythological literatures in the past. Doing so, the functionalists in India have failed to provide explanation for the empirical caste, gender, tribe and agrarian class in India. The subaltern dalit, tribal and gender have been trying to come out of the tragedy of structuralfunctional-based life, but they cannot do so. In fact, the construction of the Indian social systems (family, caste, gender) as facts or model behind the facts are, though highly looked down upon globally, however, reconstructed through sociological and anthropological studies and understandings in India over the decades. Since beginning, the no-changers have been dominating the pro-changers in the Indian sociology. The later groups assumed to be the subaltern caste, tribe and gender who have been struggling hard to be located in a space for their recognition and self respect in Indian sociology, whereas the mainstream people, dominant castes and their so called great traditions have been comfortably set in it. Unfortunately, the authentic essence and liberating presence of the subaltern groups in Indian sociology is largely missing. Besides the structuralfunctional perspectives there are other theoretical perspectives which hold the truth differently. However, it is not less than a critical heart searching through different sociological perspectives for the subaltern dalit, tribal and gender in India. Thus, an analytical reviews but critical history can suffice to our purpose under the study.

\section{III.2. Searching through Early Travelers' Accounts}

In the early history many foreign travelers, scholars and traders came to India. Their accounts of Indian society were found to be observational and empirical to the large extent, but lacked research spirit, and remained detached from the methodological tools and techniques as generally used in social sciences. The Greeks, Romans, Jews, Chinese, Arabs, Turks, Afghans and Persians wrote on what they had observed, heard and experienced about Indian people and their societies at that time (Singer and Cohn, 1968). However, what they studied that was result of their consequent visits and sightseeing in India. Interestingly, they could not observe the inner world of Indian society where the dynamics of lower castes, dalits, women and marginalized tribes were persisting. Some of them explained the class divisions of Indian society, but hardly noticed India's Varna division at that time. For instance, Megasthenes reported seven occupational classes such as philosophers (who performs sacred rites and sacrifices), herdsmen, shepherds and hunters, traders and bodily laourers, fighting men, inspectors and counselors and assessors of the king (ibid). It seems to be the real picture of Indian society without any mythical and historical data. They provided their narrations about the spaces in context, and its inbuilt socio-cultural recurrent life situations of the people at that time. It was the Arabic accounts of Indian society by Al.Biruni in 1030.A.D. and Abul Fazal in $16^{\text {th }}$ century revealed the existence of Varna division of Indian Hindu. But the Varna structure was not observed in the operational level of Indian society at that time (ibid).

Figure 4: Sociological Knowledge Developed and Used in India

\begin{tabular}{|l|l|l|l|}
\hline Knowledge Bases & Ideology to Understand Society & $\begin{array}{l}\text { Approaches to Study } \\
\text { the Society }\end{array}$ & Application in Real Life / in Society \\
\hline Travelers' Accounts & Human Tendency/Expediency & $\begin{array}{l}\text { Observational/ } \\
\text { Firsthand Experience }\end{array}$ & $\begin{array}{l}\text { Quest for Information/Knowledge\& their } \\
\text { Dissemination }\end{array}$ \\
\hline Orientalists' Views & $\begin{array}{l}\text { Expertise on Knowledge and } \\
\text { Language of Eastern World }\end{array}$ & Textual & $\begin{array}{l}\text { Macro-Picturization of Culture and Customs of } \\
\text { Everyday Life of Eastern World. }\end{array}$ \\
\hline Missionary Views & Proselytizing/Human Service & Contextual/Spiritual & Leading Christian way of life \\
\hline British Official Accounts & Political Ideology & Contextual/Official & Social and Administrative Reforms/Purpose \\
\hline Village Point of Views & $\begin{array}{l}\text { Holistic but Field Based } \\
\text { Knowledge }\end{array}$ & Contextual/Field View & Comparative Study/ Academic Need \\
\hline
\end{tabular}

Source: Our Own

\section{III.3.Searching through Early European Accounts}

The early European (Portuguese, administrators, merchants and priests) accounts on Indian society reflected something about the caste society- the high positions of Brahmins, caste based political organization, caste based customs, commensality, etc in a macro-level of the Indian society (see, Singer and Cohn, 1968 and Inden,1990). But they started emphasizing the micro-level analysis of Indian social reality. Of course, it was not 
the faults of the researchers or foreign travelers who came to India, but the Indian informants, mostly the higher castes/pundits who deliberatively provided such macro-superficial information to them about Indian societies at that time. Since knowledge base on ground realities of Indian societies not represented by the informants to other respective observers, it became informant centric. It may be assumed that, what the subalterns found in this approach that what the higher caste thought about them (subalterns) and the European accounted that accordingly, but not what they had for themselves (subalterns).

\section{III.4.Searching through Orientalists'Accounts}

The orientalist writers from western countries believed that the knowledge on Indian society cannot be possible without studying the Indian religious texts, and without cooperation of Sanskrit Pundits/Shatris (scholars of Hindu scriptures) (Singer and Cohn, 1968). They were convinced that Indian texts were adequate guides to the culture and society of India. The orientalists like N.B.Halhead tried to compile and translate the Hindu Dharma shastra/religious texts for understanding the Indian social realities (ibid). But their views on Indian societies turned to be highly religious speculations, and religious/textual of highest order. According to their understanding and studies the Brahmins were the dominant groups in the society and centers of Indian social orders. Consequently, the importance of other castes, untouchable, women and tribe remained missing in the society at that time. In fact, they could not go beyond the picture of Indian society as being static, timeless and space less, and the role of Hindu religion in it. The Orientalists did not attempt to study the practical Indian world view in which the people's life was attached with the operation of many societal systems-economic systems, social systems, legal systems, political systems, etc, Since the Hindus scriptures did not care to mention the other segments of society as important as twice born castes, and also prioritize the great traditions over the little traditions, the orienatlists could not notice the diversified and contradictory world views of untouchable, women and tribal in particular. Moreover, with the pride of being Europeans, the European orientalist writers themselves could not get rid of their dualism of the "Orientalism" versus "Occidentalism" by which a value free projection of Indian society got extinguished at that time.

\section{III.5.Searching through the Missionary Accounts}

The missionaries reported how Brahmins and their Varna/caste systems spoiled the Indian society by which the marginalized masses including women suffered from discrimination, inequality, injustice and casteism in the Indian society. They, in fact, condemned, criticized and ridiculed the Hindu social systems caste system, slavery system, Sati system, Purdah system, practices of the veneration of the cows and of the idol worships, etc (Singer and Cohn,1968). And instead, they suggested the affected people to convert into Christianity for improving their social conditions (ibid). The ethnocentric bias as how the missionaries thought that the Christianity was a better religion than any other religions in India also underestimated that Indian dalit and tribal as backward Hindu, and as if, they did not hold any rationality comparison to the Europeans. As a result, the missionaries also could not account the authentic view points of the subaltern caste, dalit and women that the latter people what could make about themselves at that time.

\section{III.6.Searching through the British Officials' Accounts}

The British official views on Indian society developed by the regional administrators, census officers and official ethnographers, though largely based on the data generated through questionnaire, reports, survey and other ethnographic inquiries, but incomplete and complex (ibid). James Grant and John Shore had firsthand experience of the Bengal society through their field studies (ibid). The official ethnographers like H. Risley, Nesfield, Ibbedson, J.H.Hutton and others though were more field oriented in their studies, but the data they collected on Indian society and land tenure systems were meant primarily for British administrative purpose (ibid). For the first time, though, a plethora of information about Indian people including marginalized groups was collected by the census officers and official ethnographers, but that was based on administrative reasons. It seemed that the marginalized sections did not have any voice in it. Rather, the top down approach on Indian social realities were deliberately promoted at that time.

Figure5: Sociological Knowledge Developed and Used in India

\begin{tabular}{|l|l|l|l|}
\hline $\begin{array}{l}\text { Theoretical } \\
\text { Perspective/ }\end{array}$ & Ideology to Understand Society & Approaches to Study the Society & Application in Real Life/ Society \\
\hline $\begin{array}{l}\text { Indological } \\
\text { Perspective }\end{array}$ & Holistic/Religious/Hinduism & Textual/Contextual & $\begin{array}{l}\text { Religious/Philosophical Value/ Book } \\
\text { Views }\end{array}$ \\
\hline $\begin{array}{l}\text { Structural- } \\
\text { Perspective }\end{array}$ & Ideology of Social Anthropology & System Approach & Holistic/Functional/Field Views \\
\hline $\begin{array}{l}\text { Marxist } \\
\text { Perspective }\end{array}$ & Conflict Sociology/ Dialectical Discourse & $\begin{array}{l}\text { Negation/contradiction in social } \\
\text { structures (Historical/dialectical } \\
\text { materialism) }\end{array}$ & $\begin{array}{l}\text { Class based analysis/ understanding life from class in itself to } \\
\text { class for itself }\end{array}$ \\
\hline $\begin{array}{l}\text { Subaltern } \\
\text { Perspective }\end{array}$ & $\begin{array}{l}\text { Ideology from below- Dalit, Tribal \& } \\
\text { their consciousness }\end{array}$ & $\begin{array}{l}\text { Practical (educational and } \\
\text { organizational ) }\end{array}$ & $\begin{array}{l}\text { Searching Authentic } \\
\text { Autonomy/ Identity/Right/ }\end{array}$ \\
\hline $\begin{array}{l}\text { Feministic } \\
\text { Perspective }\end{array}$ & Critical Sociology of Gender & $\begin{array}{l}\text { Gender Approach } \\
\text { (Feministic methodology) }\end{array}$ & Searching Authentic Identity/Right/ \\
\hline
\end{tabular}




\section{Source: Our Own}

\section{III.7.Searching through the Indological perspectives}

The indology refers to the study of Indian classic, literatures, languages, culture, etc in India. It largely reflects on the Sanskrit literature, Pali literature and the literatures related to the great Indian religionsHinduism, Sikhism, Buddhism and Jainism. In broader sense, it emerges in the academic world of specificities"indigenous knowledge base" of the Indian subcontinent that includes the neighboring nation-states of India and Asia continent in general. Contrary to the Eurocentric knowledge bases and the methods, the Indologists have strived hard on the indigenous sources and methods for studying Indian society. To have a precise account of Indian society, the orientalists largely relied on the ancient texts, whereas the indologists contextualize the textual views by emphasizing the views of texts over the contexts. The indologists are concerned with both past and present of the Indian social realities. But the problems is the quantity as how much texts or how much contexts are to be applied for studying the Indian societies. In fact, it had hardly any text that goes with any contexts. For instance, it pleads the structural pattern of Varna system without taking into account of its regional variations, and of India's operational units- caste, sub-caste, Jati, Jajmani systems, kinship systems, etc. For instance, G.S.Ghurye, the eponymous figure of Indian sociology who immensely contributed to the growth of the subject sociology, ardently argued that the knowledge of Sanskrit language is indispensable in conceptualizing any Indian social phenomena (see, Ghurye, 1943/ 1969). He also argued that Hindu ritual and ceremonies play significant role in every Indian life. He though, had empirical study, largely glorified the Indian civilization and Brahmin cultures in general (Nagla, 2008). His Brahiminical approach to caste systems and assimilation approach to tribal problems are highly impractical and remain detached from the existential realities. He was also highly biased against other segments of the societies. He more often argued that schedule caste, schedule tribe, backward classes, Muslim, other religious minority groups and linguistic minorities are as five sources of dangers for the Indian unity. On contrary, he glorified the role of Indian Sadhus or Sanyasin for the integration of Indian society (ibid). In fact, he argued that how the kinship and caste systems in India served as integrative role in the past (ibid). He was as if, thankful to the Brahmins for their role of legitimizing the caste ranks and orders through their interpretations of Dharmsashtras. He did not agree with Elywn's Isolationist Approach nor Nehru's Integrationist Approach to the problems of Tribes and their status in the Indian society (see, Nagla, 2008 and Ghurye, 1943/1969). He believed in the process of Hinduization, and for that matter, he pleaded the assimilation approach for the development of the tribal and their social status. In doing so, he argued that they are the backward Hindus. But, he did not answer as to which caste they belong, if they are Hindus. The ritual structures- purity and pollution to which the every dalit more often disregards and rejects, but Ghurye approves that are as integrative forces. This is nothing but a "blind ritual reductionism" that never allows any dalit or any tribe to live a real human life remaining in the clutches of Hinduism. In this sense, he created a Hindu sociology.

Let us comprehend another dominant Indological study conducted by L.Dumont in early Indian sociology. The Dumont's explanation of caste hierarchy is religious in nature, as what is religious that is society and vice versa is the core of his ideology. Dumont's romanticization of the Indian hierarchical orders of which the parts are synchronized on the basis of the principles of "encompassing" and "encompassed" is far from the contextual reality. In fact, the "Homo Hierarchicus" the concept connoted by him was only to show the western world that how hierarchical holism is not necessarily the opposite of inequality, but an interconnected caste society that persists as one of the most stable orderly systems in the world (Nagla,2008; Singhi,1996 and Dumont, 1970). It is not for the formation of dalit and gender identity apart from the merged identities within in it. It is another intellectual hierarchy in which subjugation, inequality and subordination, as if cannot be challenged by any subaltern and feministic intellectuals in India. The empirical reality of caste is not the superstructure but the infrastructure (Gupta, 1994). The Indologists did not notice the human meanings of caste as perceived by the Berreman- power and vulnerability, privilege and oppressions, honour and denigrations, plenty and want, reward and deprivations and security and anxiety. According to F.G.Bailey sociology does not consist only of a sociology of values because what the people belief and think is not the whole field of sociology (Singhi, 1996). Treating Aryans, Dravidians, tribes and castes at par reveals the Indologists' ignorance of the complexity of Indian society (Nagla, 2008; Singh, 2004 and Singhi, 1996). He also argues that the tribes and villages exist as the sociological realities independent of the caste system. In this regard, the structural functional perspectives on Indian society are also not less criticized in India.

\section{III.8.Searching through the Structural functionalistic perspectives}

Though, the structural functionalists come out from the text to context and from book views to field views of Indian society, they are not free from their conservatism and status quoism. And remaining so, they cannot explain many conflicting and contradictory elements of Indian society. M.N. Srinivas's concept of "Sanskritization" and "westernization", M.Marriot's concept of "Universalization" (how little traditions get merged with great traditions) and "Parochialisation" (how great traditions get merged with little traditions), Redfield's concept of "great traditions" (mainstream traditions) and "little tradition" (local traditions of little 
community) are some of the processes of social dynamics in Indian society (Marriot, 1990; Redfield, 1965 and Srinivas, 1962). But the structural functionalists instead of, acknowledging the concepts as two way processes of change, reflect the divide between the two cultural patterns, as if in one way for the functional unity in the society. And that perpetuates the importance of the process of Sanskritization, Universalization and great traditions over the processes of westernization, Parochialisation and little traditions in the Indian society.

The essence of the structural-functional framework and its intensive fieldwork traditions have been clearly reflected in the works of Srinivas in south India. Though, he greatly followed Radcliffe Brown's structural functional approach, but differentiated himself from his teacher in many important ways that a serious researcher cannot ignore. First, Brown's study was on Tribal society, whereas his study was on caste society in India. R. Brown did not have any significant study on how there was functional unity among different castes or between the tribes and castes as inclusive categories in Indian village. It was Srinivas who brought Brown's ideas to study the caste community in Indian village. Probably, why did R. Brown not locate a caste village for his anthropological study or a village inhabitated by both caste and tribal people for the same? Why was an isolated tribal village taken by him for the study? On the other hand, why did Srinivas not choose the tribal village or both tribal and caste village inclusively for his study? Why R.Brown did not suggest Srinivas to study Tribal society? Why functional inquiry on dalit, gender, tribe and caste did not go together? Unfortunately, these questions are not openly discussed in India. As a result, the structural-functional approach of Brown and Srinivas was not developed further, in the educational institutions. In fact, although the early Indian sociologists followed the structural functional perspectives, they greatly neglect its approach to study of the Indian society. A sociologist never relies on his memories for narrating his study nor can develop a research book entirely based on his memories. Unlike sociologists and anthropologists Srinivas has written his book- remembered village- Ramapura. It is very difficult to say that he was not biased in his writing or presentation of his understanding about Rampura village. It may be assumed that Srinivas theory is largely, qualitative as for instance, the methods and tools he used in his study- the folklore, fictions, personal questionnaire, participatant observations, etc made his analysis highly interpretative, reflective and phenomenological in nature (see, lynch,1977 and Singhi,1996). In fact, as a Brahmin, he initially used the word Brahminization to explain the process of change among lower castes in Rampura village. Since he was a south Indian, he was preoccupied with the ideas of purity and pollutions, rites and rituals, intercaste conflict, backward class movements, etc of south Indian villages. He wanted to reflect on, and reconstruct the traditional cultures of coorg village. $\mathrm{He}$ developed the concept Sanskritization in order to explain the spread of Hinduism. For instance, Srinivas though, pleads for change in caste system through the processes like "westernization" and "modernization", but stressed on the process of "Sanskritization" as the Brahminical Hinduism. In the name of Sanskritization, he therefore, marginalized and alienated religious minorities and subaltern castes and tribes in the Indian society. His stand on Indian society is caste society, and that too higher caste tradition is the real tradition, and no other tradition except Brahaminical tradition explains the real Indian society. Srinivas credited with the concepts of "Sanskritization" and "Dominant caste" not because of his uniqueness of explaining the caste dynamics in the village level, but how these concepts loose break of the unchanging hierarchy that persists between Brahmans at the top and untouchable at the bottom as justified by the Hindu scriptural texts. And, the dominancy of any caste by any other caste on the basis of their material possession, numerical strength, economic development and political power was his empirical data that also breaks that the dominancy of ritual status over secular status. However, it is only a positional change that could not bring any effect on varna/caste-based hierarchism. Rather, it perpetuates and propagates that the great traditions of Sanskrit Hinduism are with twice born castes, and not with lower caste. Therefore, the dalits and tribal have to follow the Sanskritic dharma. He did not make any path breaking study on a complete Indian village comprising Hindu, Muslim, other minorities and tribal, and most importantly on the theme whether gender dimensions would be the functional imperatives or not in village India for his functional arguments.

But to some extent another structural-functionalist S.C.Dube tried to study the complete Indian village consisting of Hindu and non-Hindu community in rural India. He also highlighted the roles of women in five major activities i.e. domestic work, agriculture, festival and ceremonies, birth, marriage and death and village administration and politics (see, Nagla, 2008; Singhi, 1996 and Dube, 1958\&1952). However, while analyzing the status differentiations of the people, he did not take into the gender factor. He only discussed the factors such as religions, caste, wealth, leadership, position in government service and village organization, age, land ownerships and distinctive personality systems (ibid). Further, his understanding of caste is quite similar to that of Srinivas, and of Ghurye as stated earlier. Rather, he is more close and open to the indologists' views against colonial, American and European conceptions of Indian social realities. According to him the Indian ancient texts were not necessarily deep rooted through the contents of early Indian metaphysics and philosophy. Instead of, he argued that the ancient texts provide many testimonies of existential realities of Indian society. For instance, Indian Dharma shastra are not utopias as these provide the analytical structures such as Desha (place/country), Kala (time) and Patra (persons/social categories). And beside Dharma Shastra, there were 
Kautilya's Arthashastra on effective administration; Charaka's art and science on healings, the materialistic approach of the lokayat philosophers, etc (see Singhi, 1996; Nagla, 2008 and Mukherjee, 1979). But, like any other Indologists and structural functionalists, he did not dare to expose the cruel indigenous sources of cultural violence on women and dalit in rural India. Unlike Srinivas, he experienced the social change through the process of modernization and community development programmes in the village level. While Srinivas did not like American texts books, Dube did not like academic colonialism and neo-academic colonialism as sources and agencies for the understanding of Indian social realities (Nagla, 2008 and Singhi, 1996). Both of them unfortunately, did not mention any thing suggestive for the study of the women and dalit and their suffering in the society. Srinivas advised the tribal to go for Sanskritization while Dube emphasized the importance of community development programmes and modernization for their development in the society (Nagla, 2008 and Dube, 1958). Sometime, S.C.Dubey's interdisciplinary approach and Srininvas's Hindutva ideology on Indian social realities make them to go beyond their incorporation into the structural functional school of thought in India. However, their approach and perspectives on Indian society are not comfortably integrated in any major academic and non-academic studies in the contemporary society. Their theoretical analysis is greatly based on the assumptions that how Indian society remains cohesive and stable with different structural arrangements without producing any conflict and contradictions.

\section{III.9.Searching through the Marxist Perspectives}

Unlike earlier perspectives, the Marxists perspective recognizes the dialectics of evolutionary and revolutionary changes reflecting the realms of contradictions, conflicts and radicalism in the Indian society. The Marxist perspective gives central importance to the property structures in analyzing any society (Desai, 1966; Nagla, 2008 and Singhi, 1996). It provides historical locations of the social phenomenon, and studies their specificities in the context of relation of productions. In order to understand the social realities, the Marxists have applied three important aspects such as nature of means of productions, techno-economic division of labour for productions and social relation of productions (ibid). Marxists argue that previous conception of history either neglected the real basis of history or made real basis secondary without any connection with the actual course of history (ibid). The presupposition of all human existence is that man has to live in order to make history, and the first historical fact is the production of material life itself than anything else as argued byA.R. Desai. In this sense, they give more priority to the material existence over societal value structures. A.R.Desai argues that the Marxists do not ignore the importance of the institutional structures like caste, religions, kinships and ethnicity, etc peculiar to Indian society. And rather, Marxists tried to explain them in term of the property relations. But other perspectives ignore the importance of Marxist perspectives. He argues that India today is developing not because of her great cultural values or proud civilization, but for her economic planning and capitalistic development over the years. And also remains underdeveloped due to her problems of poverty, inequality, and economic backwardness. Thus, we cannot undermine the economic analysis of Marxist perspective in Indian situation. But the whole complex of socio-cultural systems, religious and linguistic diversities, gender and caste dynamics, political conflicts, regional disparity, marginalization of tribes and dalit, etc cannot be economized or materialized in one connection. This perspective has been highly criticized because; it is based on naive economic determinism, violent conflicts, capitalistic system, class struggle, etc (Singh, 2004 and Singhi, 1996). In fact, neither A.R.Desai, nor D. P. Mukerjee and R. K. Mukherjee have ever produced any unique methods for the field study on any socio-economic issues in India. In India as in elsewhere, the Marxism has become something like opium of the intellectuals. And it runs away from non-class based realities of Indian societies.

\section{III.10.Searching through the Subaltern Perspectives}

This subaltern perspective came from History to Sociology and became controversial, not because it lacks its kernel of theorizing and concern for theory building, but it is the perspective which not only dissociates itself from each other above perspective, but also criticizes them vehemently. Indeed, it has been taking new departure challenging the gateways of the established theoretical patterns in the Indian sociology for a greater intellectual legitimacy. R.Guha rightly perceived that the subaltern studies have enough possibility of projecting, constructing and analyzing the people's lives, institutions, movements, values, and processes of their formations, structuration and restructuration at local and regional level (see, Nagla, 2008; Singhi, 1996 and Guha, 1982). The subaltern persons/groups are not homogenous persons /groups as they are not only castes or only men or only women. But they may be proletariat, peasants, dalit, women and others, but subordinated, marginalized and voiceless staying at the margins of the society, and outside of the hegemonic power structures (Nagla, 2008; Guha,1982; Singhi, 1996 and Dhanagre, 1993). The "Dalit Bahujans" that includes all backward castes/classes who have been oppressed and depressed, and have been struggling hard for their survival and identities as discussed by Dr. B.R.Ambedkar, and those tribal in south Gujarat who organized themselves "Devi movement" for their social transformation against the exploitative systems of local Sarkar (government), Shaukar (moneylender) and Zamindar (landlord) as explored by D.Hardiman are the subalterns in India (Hardiman, 1996 and 1987; Nagla, 2008). Devi movement was a peaceful and non-violence social reform 
movement led by the tribal themselves to refrain from their traditional practices of liquor habits, nonvegetarianism, superstitions, bodily uncleanliness, etc. Their transformation was neither programmed on the basis of "Sanskritization" as perceived by M.N.Srinivas nor preached on the basis of "non-violence strategy" as practiced by the M.K.Gandhi. In fact, the tribal changed themselves following the commands of the "Devi". The "Devi" was believed to have expressed through the mouth of spirit medium, her commands such as stop drinking liquor and toddy, do not eat meat and fish, live a clean and simple life, take regular bath, etc (ibid). In fact, the tribal brought this movement successful for themselves. Hardiman argued that this movement was neither noticed nor believed by any government official and researcher at that time (see, Nagla, 2008 and Hardiman, 1996 \&1987). Rather, it was wrongly believed that the tribal were sanskritized and strictly followed Gandhian principles for their social transformation at that time. It is because, the cultural elite always undermine the inner strength of masses- the dalit Bahujans to which the subalternists like B.R. Ambedkar, R.Guha and D.Hardiman highly condemned.

The untouchable also initiates social movement for their reformation and upliftment. The dalit simply apply the democratic strategy for their rights and equal opportunities in India. Unfortunately, except subaltern studies and dalit scientists like Dr.Ambedkar, none of the sociologists could dare to search the inner strength of the subaltern caste, tribe and women in early Indian society. Further, many mainstream sociologists are still struggling hard on mainstream Indian values and classical thoughts for mental satisfaction. In fact, some Indian philosophers- the lovers of the ancient knowledge and wisdoms still remain highly complex and complicated on the subaltern issue/identity favouring the mainstream Indian society. It is also not untrue that the Indian social scientists like Dr. B. R. Ambedkar who made stringent efforts to expose the sterile/mythical intellectualism which nurtures the culture of casteism, patriarchy, Hindu hierarchical structuralfunctionalism, purity and pollutions, etc in rural India (Ambedkar,1979 and Nagla,2008). But this was more a historical fact as no dalit ever became like Ambedkar to do so. Ambedkar could raise the subaltern issues basing on his interdisciplinary experiences as he was no doubt a pragmatist and progressive versatile scientist of many disciplines in one- philosopher, historian, economist, anthropologist, sociologist, Indian jurist, so on and so forth. His critical understanding on Indian social realities is based on his different path breaking research and studies- case studies, doctoral and post doctoral studies, political election studies, studies on important documents and archives, manuscript and texts, etc. He was himself a subaltern person who could realize the false caste/class/gender consciousness remaining attached in the social structure of hierarchical Hinduism. He advised and rather, experimented that the Dalit Bahujan must know that their human liberty and self elevation are neither the gifts they would receive from any authoritarian structure nor the blessings they would get from any religious elites (ibid). He cautioned that many Mahatmas emerged in India, and disappeared so soon, but could not do anything for the dalit, and rather made them grappling with the process of confusion and mental slavery. He argued that unless and until the subaltern themselves fight their own battle against all odds and obstacles that come in their everyday lives, no one else could do that for them. But he cautioned that without self education, the subaltern cannot have critical understanding, and without critical understanding they may not have right agitation, and without right agitation they may not have strategic organization. And without self education, critical understanding and strategic organization they cannot rescue themselves of their mental slavery, socio-economic subordinations and century long marginalization in the society. Unfortunately, hardly any mainstream sociologists could explore this liberating formula for the subalterns in India. His century lasting slogan/line for the subaltern - educate, agitate and organize is therefore, the liberating human principles that has been a rare intellectual strategy found in the human history (Ambedkar, 1979).

Dr. B.R. Ambedkar not simply propagated his research finding but also practiced these principles in his life time. For instance, he launched a journal "Mook Nayak" in 1920 and "Bahishkrit Bharat" in 1927 in educating the Dalit Bahujan, the danger of the Hindu hierarchical, brahminical, and patriarchal social order that how persists over the years. He had formed the Bahishkrit Hitakarni Sabha in 1924 for the socio-political equality and economic mobility of the depressed people. In order to become practical and rational in his approach, he was successful in organizing the social movement, whether it was his temple entry movement or public water use protest in his life time. He could mobilize the people to burn the Manuscript not for any political purpose. In fact, he was brain child making and passing of the Hindu Code Bill in the parliament. But for the political game of congress, there were stiff oppositions to this bill at that time. Consequently, he resigned from his position of law minister in Nehru's cabinet. This shows his commitment for the cause of women in general. In fact, he got materialized his radical progressive ideology with his actions. Fortunately, later time, most of the provisions proposed by him such as Hindu marriage act, Hindu succession act, guardianship act, maintenance act, etc were got passed what he wanted for women's rights. He could also introduce the Maternity Benefit Bill for working women when he was labor mininister. The hosts of other articles, social legislations, amendments, acts, provisions, policy, so on and so forth initiated by him have made a significant contribution to the subaltern consciousness in the Indian society. But it is worth mentioning here that for a legitimate space in the Indian sociology, the subaltern studies have been undergoing scrutiny by the so called "mainstream sociologists" for last several decades (see, Singhi, 1996; Ambedkar, 1979 and Bhal, 2002). It is because of the fact that the Indological hegemony, and its related functional ideology still persist, like "cultural watchdog" against any possibilities of the subaltern perspective in contemporary India.

\section{Conclusion}

However, we can conclude that going beyond the prospects of structural-functional perspective in Indian sociology will certainly be an uphill task for the sociologists in general. But, except subaltern 
perspective, going right through structural-functional perspective, Indological and Marxist perspectives and colonial historical accounts, it has been a crucial heart searching for the so called "subalterns" and their authentic identities and autonomies within Indian sociology for last several decades. Addition to that, our critical overviews of the related literatures available in early Indian sociology, under the study reflects a distorted and incomplete picture of the subordinated dalit, marginalized tribal and voiceless women to a large extent. It is a historical fact that the foreign travelers, scholars and traders (Greeks, Romans, Jews, Chinese, Arabs, Turks, Afghans and Persians) who visited India, wrote on what they had observed, what they had heard from the cultural elites (Indian scholars, poets, priests, pundits, etc) and what they had experienced about Indian people and their societies in early Indian history. The foreigners' accounts of Indian society therefore, were assumed to be observational and empirical to a large extent. But their accounts lacked the spirit of actual research, and remained therefore, far away from the methodological tools and techniques generally used in social sciences. Interestingly, without having any quest for objective research, they could not observe the inner world of Indian society where the dynamics of lower castes, dalits, women and marginalized tribes were missing or emerging. Contrary to it, the British official ethnographic accounts of Indian society was largely based on research findings. However, it also could not touch the ground realities of Indian villages from village point of views to a great extent. Since the knowledge base on ground realities of Indian societies not captured from the horse mouth directly, or represented by the informants casually, the official ethnographers and other respective observers largely remained ignorant of the undercurrents and discontentment of the subaltern Indians in the rural settings. It was therefore, assumed to be highly informant centric. The informants, mostly the higher/dominant castes presented the macro-superficial information to the British officials at that time. Moreover, with the pride of being Europeans, the European orientalist writers themselves could not get rid of the feeling of the superiority complex of "Occidentalism" over "Orientalism" by which a value free projection about Indian society, and its marginalized sections got extinguished at that time. The ethno-centric bias as how missionaries thought that Christianity was a super religion than any other religions in India also underestimated that Indian dalit and tribal belonging to Hinduism as backward- as if, they did not hold any rationality comparison to Europeans. Though, a plethora of information about Indian people including marginalized groups was gathered by the census officers and the British official ethnographers in colonial India, but that was merely collected on administrative reasons. It seemed that the marginalized sections did not have any voice in it. Then after, in order to revitalize the "Indianness" in Indian sociology, the Indologists started criticizing the locus standi of colonial ethnographic studies, western positivistic epistemology, and host of other Eurocentric concepts, theories, thoughts, ideologies, etc, and also the processes of westernized change in a very substantive ways. In course of time, the theoretical discourses on Indological perspective propounded by the eponymous figures of Indian sociology like G.S.Ghurye and L. Dumont as stated earlier, therefore, became quite suggestive for the confluence of Indian sociology and Indology leading to the process of "Indianization". Consequently, in post-Independence India, the Indology and Culturology have been heralded, as if, the prototype of Indian sociology. But this is not true. Therefore, the structural functionalists did not accept the Indology and mythologized history, and also argued that simply criticizing the western paradigm, positivism and philosophy would be misleading for the Indian sociology without comprehending their relevance in Indian situations. The study from texts to context at ground level, which is the village study, was greatly emphasized by them for Indian sociology. But the "teleology" and "tautology" inherently affixed with the structural functional perspective- remained doubtful to the very peoplewomen, dalit and tribal who have been surviving in a life of compromise, contradiction and conflict in the Indian society for centuries. Thus, in course of time, this prospective was highly charged by the Marxists in India. The Marxists tried to evolve or rather promoted reactionary movement against the existing social order/super-structures- religions and polity prevailing in Indian society. The Marxists have also been miserably failed to evolve any unique methodological tool and technique that everybody irrespective of his/her affiliation to different theoretical perspectives can apply in any study comfortably. In fact, the dialectical perspective could trigger such an intellectual atmosphere in Indian society by which the Marxism has become opium of the Marxist intellectuals themselves.

If truth be told then except subaltern perspective, none of the sociological perspectives could be the people's perspectives, and instead, became the elitist perspectives which have, of course, endeavoured to touch the ground Indian social realities from the top but not from the bottom. Therefore, all of these perspectives get structured by the intellectual elite, of the mainstream society and for the few dominant social groups in the Indian society. It is because of the fact that the questions of dalit, tribal, peasants, tenants, and landless people, and of other such marginalized poverty stricken people and voiceless women have been neglected by these perspectives in Indian sociology. Perhaps, because of this dualism and discrimination, such marginalized groups' authentic strength gets reinforced in the making of the subaltern perspective throughout India at present. In this regard, of course, the subaltern perspectives furthered by R. Guha are few and far between in Indian history. However, it is such a perspective where all subordinated, marginalized and voiceless sections- tribe, caste and gender can flexibly be incorporated for their authentic, original and inclusive rights, dignities, 
humanities, etc in the society. Ambedkar himself was a dalit who tried to study his own society from his own perspective, had high visions and missions for the subaltern groups. Unlike the dalit scientists and dialectical /critical feminists, the mainstream sociologists who claimed themselves as spokespersons for the subalterns' rights and identities, either have sympathized the victimized dalit/tribal/women or empathized their plights in their findings. But knowingly or unknowingly, they have distorted the subalterns' authentic ethnicity and identity arguing in favour of the dominant ideology in Indian sociology. Whether, it is the study of Hardiman's Devi movement in south Gujarat or the study of Ambedkar's dalit movement in Maharashtra, the findings have been the self awakening and self searching movements against the oppressive and repressive apparatus of so called India's mainstream society, and also against the deliberate discourse of the "elitism" which has been engulfed in the Indian literary world for centuries. However, the subaltern consciousness as an alternative intellectual project requires a progressive debate for the sociology in India. Addition to that so far, the prospect of the dalit feminism, tribal feminism and feministic subalternity in general has not been greatly realized in the subaltern perspective, although not neglected in India. Because of the fact, the historiography as a method of research inquiry is largely neglected in the sociological research and course curriculums worldwide.

\section{References}

[1] S.Patel, (ed.), The ISA Handbook of Diverse Sociological Traditions, (Los Angeles et al: Sage.2010)

[2] B.K. Nagla, Indian Sociological Thought, (Jaipur, Rawat, New Delhi: Vikas,2008)

[3] Y.Singh, Ideology and Theory in Indian Sociology, (Jaipur: Rawat Publications, 2004)

[4] D.Veena, (ed.), The Oxford India Companion to Sociology and Social Anthropology, (New Delhi : OUR, 2003)

[5] M.N.Srinivas, Caste: Its Twentieth Century Avatar, (New York: Penguin Putnam Inc.1997)

[6] N.K.Singhi, (ed.), Theory and Ideology in Indian sociology, (Delhi: Rawat Publication, 1996)

[7] G.Ritzer, Sociological Theory, (New Delhi: Tata-McGraw Hill, 1996)

[8] K.S. Singh, 'G.S. Ghurye, Verrier Elwin and Indian Tribes', in A.R. Momin (ed.) The Legacy of G. S. Ghurye, (Bombay: Popular Prakashan,1996)

[9] D.N.Dhanagare, Themes and Perspectives in Indian Sociology, (Jaipur: Rawat,1993)

[10] M.N.Srinivas, 'Sociology in India and its Future', Sociological Bulletin, 43, no. 1, 1994

[11] T.K. Oommen, \& P. N. Mukherjee (eds.), Indian Sociology: Reflections and Introspections, (Bombay: Popular Prakashan, 1986)

[12] Y.Singh, Indian Sociology: Social Conditioning and Emerging Trends, (New Delhi: Vistaar, 1986)

[13] R.Mukherjee, Sociology of Indian sociology, (Bombay: Allied Publi-shers.1979)

[14] G.Sarana, Structuralism, (Jodhpur: University of Jodhpur.1979)

[15] B.R. Ambedkar, 'Castes in India: Their Mechanism, Genesis and Development', "Castes in India” in Dr.Baba Saheb Ambedkar: Speeches and Writings, Vol.I, Education Department, Government of Maharashtra, 1979

R. Mukherjee, 'Trends in Indian Sociology', Current Sociology, 25, no. 3 : 1-193.1977

[17] S, C. Dube, Social Sciences in a Changing Society, (Lucknow University Press, 1973)

[18] R.K.Merton, 'Structural Analysis in Sociology', in P.M. Blau (ed.) Approaches to The Study of Social Structure, (New York: Free Press, 1975)

[19] M.Singer, When A Great Tradition Modernises, (Delhi: Vikas, 1972)

[20] D.Mandelbaum, Society of India, (Bombay: Popular Prakashan,1970)

[21] M.Singer \& B.S.Cohn, Structure and Change in Indian Society, (Chicago: Aldin Publishing Co., 1968)

[22] T. K. N. Unnithan, Y. Singh, N. Singhi and I. Deva. Sociology for India.(New Delhi: Prentice-Hall of India, 1967)

[23] G.S.Ghurye, The Scheduled Tribes, the Aboriginals-So Called and Their Future, (Bombay: Popular Prakashan, 1943, 1995)

[24] G.S.Ghurye, Caste and Race in India, (Bombay: Popular Prakashan,1969)

[25] O.M.Lynch, "Method and Theory in the Sociology of Louis Dumont: A Reply." In Kenneth David (ed.), The New Wind: Changing Identities in South Asia, 239-62, (The Hague: Mouton, 1977)

[26] M.N.Srinivas, Religion and Society Among the Coorgs of South India, (Oxford: Clarendon Press, 1952)

[27] S.C.Dube, Anthropology, (Hyderabad: Chetna,1952)

[28] S.C.Dube, India's Changing Villages, (London: Routledge and Kegan Paul, 1958)

[29] T.Bottomore and R.Nisbet, A History of Sociological Analysis, (Delhi: Rawat Publications 2004)

[30] G.Ritzer and B.Smart, Hand book of Social Theory, (New Delhi:Sage, 2001)

[31] J.Turner, The Structure of Sociological Theory, (Jaipur:Rawat Publications, 1999)

[32] T.N.Madan, and D.N. Majumdar, An Introduction to Social Anthropology,(Delhi: National.1956)

[33] M. N. Srinivas and A. M. Shah, 'The Myth of Self-Sufficiency of the Indian Village', The Economic Weekly, September 10, 1960

[34] S. S. Jodhka, 'Nation and Village: Images of Rural India in Gandhi, Nehru and Ambedkar', EPW, August 10, 2002(a)

[35] S.S. Jodhka, 'Caste and Untouchability in Rural Punjab', EPW,1813-1823 V. 37 Issue. 19, 2002(b)

[36] W.E, Moore, Order and Change: Essay in Contemporary Sociology, (New York:John Wiley \& Sons, Inc,1967)

[37] S.L. Doshi, Modernity, Post-modernity and Neo-sociological Theories. (Delhi: Rawat Publication, 2003)

[38] S.F. Nadel, Theory of Social Structure, (London: Cohen \& West Ltd, 1957)

[39] R.Inden, Imagining India, (Cambridge: Basil BlacwellLtd,1990)

[40] L.Dumont, Homo Hierarchicus: The Caste System and its Implications, (New Delhi: Vikas, 1970)

[41] D. Gupta, Social Stratification, (New Delhi: OUP.1992)

[42] M.Marriott, India through Hindu Categories, (Delhi;Sage, 1990)

[43] R. Redfield, 'Primitive and Peasant: Simple and Compounded Society' in A. Aiyyappan and L.K. Balaratnam,(ed.), Society in India, (Madras: Book Centre, 1956)

[44] M.N.Srinivas, Caste in Modern India and Other Essays, (Bombay: Asia Publishing House, 1962)

[45] A.R.Desai, Social Background of Indian Nationalism, (Bombay: Popular Prakashan, 1966)

[46] R.Guha, (ed.), Subaltern Studies: Writings on South Asian History, (7 volumes, Delhi : OUP,1982)

[47] D.Hardiman, Feeding the Bania: Peasants and Usurers in Western India, (Oxford University Press. 1996)

[48] D.Hardiman, The Coming of the Devi: Adivasi Assertion in Western India, (Oxford University Press, 1987)

[49] B.R. Ambedkar, "Women and Counter Revolution", "Riddles of Hindu Women" in Dr. Baba Saheb Ambedkar: Writings and Speeches, Vol.3, Department of Education, Government of Maharashtra, 1987.

[50] B.R. Ambedkar,'The Rise and Fall of the Hindu Women”, The Mahabodhi (Calcutta), 59.5-6, 137-151, 1950

[51] V.Bhal, 'Relevance or Irrelevance of Subaltern Studies', in David Ludden's Reading Subaltern Studies, (Orient Longman, 2002) 